\title{
Wind speed characteristics and implications for wind power generation: Cape regions, South Africa
}

AUTHORS:

Marc A. Wright ${ }^{1}$

Stefan W. Grab

\section{AFFILIATION:}

${ }^{1}$ School of Geography,

Archaeology and Environmental

Studies, University of the

Witwatersrand, Johannesburg,

South Africa

\section{CORRESPONDENCE TO:}

Marc Wright

EMAIL:

marcalanwright@gmail.com

\section{DATES:}

Received: 05 Sep. 2016

Revised: 04 Jan. 2017

Accepted: 12 Feb. 2017

\section{KEYWORDS:}

wind variability; wind power; wind trends; climatology; wind forecasting

\section{HOW TO CITE:}

Wright MA, Grab SW. Wind speed characteristics and implications for wind power generation: Cape regions, South Africa. S Afr J Sci. 2017;113(7/8), Art. \#2016-0270, 8 pages. http://dx.doi.org/10.17159/ sajs.2017/20160270

\section{ARTICLE INCLUDES: \\ $\times$ Supplementary material \\ $\times$ Data set}

FUNDING:

National Research Foundation (South Africa)

(c) 2017. The Author(s). Published under a Creative Commons Attribution Licence.
Spatio-temporal dynamics of near-surface wind speeds were examined across the Northern, Western and Eastern Cape regions of South Africa. The regions assessed were geographically subdivided into three zones: coastal, coastal hinterland and inland. Wind speed data $(10 \mathrm{~m})$ were evaluated at monthly, seasonal, annual and zonal resolutions, with the aim to establish wind speed attributes and trends. Data from 19 weather stations with high-resolution wind records between 1995 and 2014 were evaluated. The majority of stations $(79 \%)$ recorded a decrease in mean annual wind speed over the study period. The mean rate of decrease across all stations over the 20 -year period equates to $-1.25 \%$, quantifying to an annual decrease of $-0.002 \mathrm{~m} / \mathrm{s} /$ year $(-0.06 \% \mathrm{pa})$. The largest seasonal decline of $-0.006 \mathrm{~m} / \mathrm{s} / \mathrm{year}$ $(-0.15 \% \mathrm{pa})$ was recorded in summer. Statistically significant declines in mean annual wind speed are somewhat more pronounced for the coastal zone $(-0.003 \mathrm{~m} / \mathrm{s} / \mathrm{year},-0.08 \% \mathrm{pa})$ than over interior regions $(-0.002 \mathrm{~m} / \mathrm{s} / \mathrm{year},-0.06 \% \mathrm{pa})$ for the study period. The largest decrease $(-0.08 \% \mathrm{pa})$ was recorded for the coastal zone, followed by the inland zone $(-0.06 \% \mathrm{pa})$, equating to an annual reduction in available energy of $0.18 \% \mathrm{pa}$ and $0.09 \% \mathrm{pa}$, respectively. When considering all stations over the study period, the mean inter-annual variability is $3.11 \%$. Despite such decreases in wind speed, the variance identified in this study would not have posed any risk to power generation from wind across the assessed stations, based on the period 1995 to 2014.

\section{Significance:}

- Mean recorded wind speed decreases have been marginal under recent (last 20 years) climatic conditions and change, thus adding confidence to the justification by the South African government to procure additional wind-generated electricity capacity.

- $\quad$ Wind speed trends and variance measured over the research period (1995-2014) for the Cape stations in this study, would not have posed any risk to power generation from wind.

- Only four stations (28.6\%) recorded statistically significant trends at the $0.05 \%$ level; of these $75 \%$ were decreasing trends.

- Coastal zones recorded a statistically larger decrease in mean wind speed compared to inland regions.

- When considering all stations over the period 1995-2014, the mean inter-annual variability is $3.11 \%$.

\section{Introduction}

Despite uncertainty in forecasting wind speed and variance over time, wind power generation is the fastest growing form of renewable energy, and thus such forecasts are important considerations for the renewable energy sector. Globally, wind energy generation has been growing at a rapid rate over the past few years, with $\sim 370$ GW of installed capacity, and growth rates in excess of $15 \%$ per annum. ${ }^{1}$ It is thus pertinent to evaluate recent South African surface wind trends in the context of wind energy generation. To this end, information relating to recent near-surface wind trends can be applied in various fields of interest, such as pollen dispersal alerts, wind erosion in agricultural settings, building engineering, and the design of wind farms. South Africa is a developing country with limited capacity to generate sufficient energy, thus the importance of establishing renewable energy sectors (solar and wind in particular). Given the global uptake of alternative energy generation, such as wind power generation, the South African government initiated the procurement of wind power in 2011 from independent power producers, aimed at diversifying and expanding South Africa's electricity generation. ${ }^{2,3}$ South Africa recorded its first wind-generated electricity from independent power producers incorporated into the national grid at the end of 2013. This generation had reached $1212 \mathrm{MW}$ by the end of 2015 , which equates to $2.66 \%$ of the national installed power capacity. ${ }^{4}$ The projected outlook would see up to $4360 \mathrm{MW}$ (approximately $5 \%$ of national power capacity) of wind generation installed by $2030 .{ }^{5}$ This substantial uptake in energy generation from wind requires some understanding of wind variability and trends in the South African context, so as to quantify the potential impact of wind variability and/or change over a 20 -year power purchase agreement term.

The most remarkable characteristic of wind is its inherent variability, both geographically and temporally. Wind speed is a function of the atmospheric pressure gradient, with the ultimate driver being the sun. Varied heating of the earth results in global circulation patterns with Coriolis forces fundamentally driving large-scale motion of the air. Wind variability at a regional scale is strongly influenced by micro-scale, meso-scale and synoptic-scale factors such as topography, water bodies (e.g. oceans, lakes) and land use. Wind variability is thus an essential indicator of atmospheric circulation. As part of an international effort to quantify climate and related circulation changes, several studies have focused specifically on wind speed variance. ${ }^{6-9}$

Studies from around the world have found variable trends in mean wind speeds over the last few decades. For instance, studies in Turkey (1975 to 2006), Brazil (1986 to 2011), China (1969 to 2005) and Canada (1940 to 2006) found that most stations were experiencing a decrease in seasonal and annual mean wind speed. ${ }^{10-13}$ In 
contrast, wind speed trends have increased in several other regions such as over the global oceans and the Baltic region. ${ }^{11,14}$ Most such changes were strongly linked to fluctuations in synoptic-scale circulation. ${ }^{15}$ Several studies in South Africa have evaluated and quantified wind distribution and frequency. ${ }^{16-19} \mathrm{~A}$ recent study statistically assessed wind speed distribution and power density in Port Elizabeth and concluded that average wind power density is highest during spring (SeptemberOctober) and lowest during autumn (April-May). ${ }^{20}$ Kruger $^{21}$ considered the impact of wind power on the South African built environment and suggested that the strong wind climate of South Africa is similar to that of southern South America and Australia, with the primary, strong windproducing mechanisms being thunderstorms and extratropical cyclones. However, there is still a research gap with respect to identifying wind speed trends and associated impacts on wind energy generation in southern Africa, and the Cape region in particular. We thus aimed to address this gap by analysing recent (1995-2014) South African wind speed data in the Cape regions, with the intention to establish recent spatio-temporal trends and variability.

\section{Data and methods}

Wind speed data from 19 stations across the Western, Eastern and Northern Cape Provinces of South Africa, covering the years 1995-2014, were obtained from the South African Weather Service. The research period was limited to years for which data were available across all stations. Stations are distributed across the study region, as indicated in Figure 1. Wind speed measurements were taken $10 \mathrm{~m}$ above ground surface, at 5-min intervals. The quality control procedure evaluated data continuity to determine potential external effects on station data.

Data uniformity checks were undertaken to minimise potential data errors. Given that considerable inhomogeneity was detected, 5 of the 19 data sets were completely disregarded, thereby reducing the number of stations considered to 14. External factors identified to have influenced such station records include station relocation, tree growth or removal, and urbanisation. The data recovery rate was $98.06 \%$ for the 14 stations, with a standard deviation of $1.7 \%$; imputed values replaced missing records. Given that it is near impossible to obtain homogeneous wind records, several previous studies have used a similar quality control approach to assess wind speed data, as that applied in our study. ${ }^{22-24}$

\section{Statistical evaluation}

Descriptive statistics calculated for wind speed data include standard deviation $\left(S D=\sqrt{\frac{\sum(x-x)^{2}}{N-1}}\right.$, mean, minimum and maximum values to provide a range of wind speeds over the 20 -year period. Daily mean wind speed data were consolidated into monthly, seasonal and annual means, thereby permitting trend analyses and the proportional variance to be ascertained over the study period. The locality of each station is placed within one of three geographic zones, namely coastal zone (0-10 km from shoreline), coastal hinterland zone (10-60 km from shoreline) and inland zone (>60 km from shoreline). The proportional variation of the mean wind speed for each station was calculated at monthly, seasonal and annual zonal resolutions (for the period 1995-2014), and linear regression methods were applied to the data. The least squares approach was applied to fit the linear regression, as is widely applied. ${ }^{25-27}$ The regression analyses indicate that four of the stations (EC3, NC6, WC3 and WC4) record statistically significant trends, with only EC3 recording an increasing trend, while the remaining stations record an insignificant trend at a 5\% significance level.

\section{Results}

Although a 20-year period is insufficient to establish conclusive changes in wind associated with climate change, the record is nevertheless able to provide tentative comparison of the data sets and indicate mean wind speed variance and trends over the last 20 years for the Cape regions.

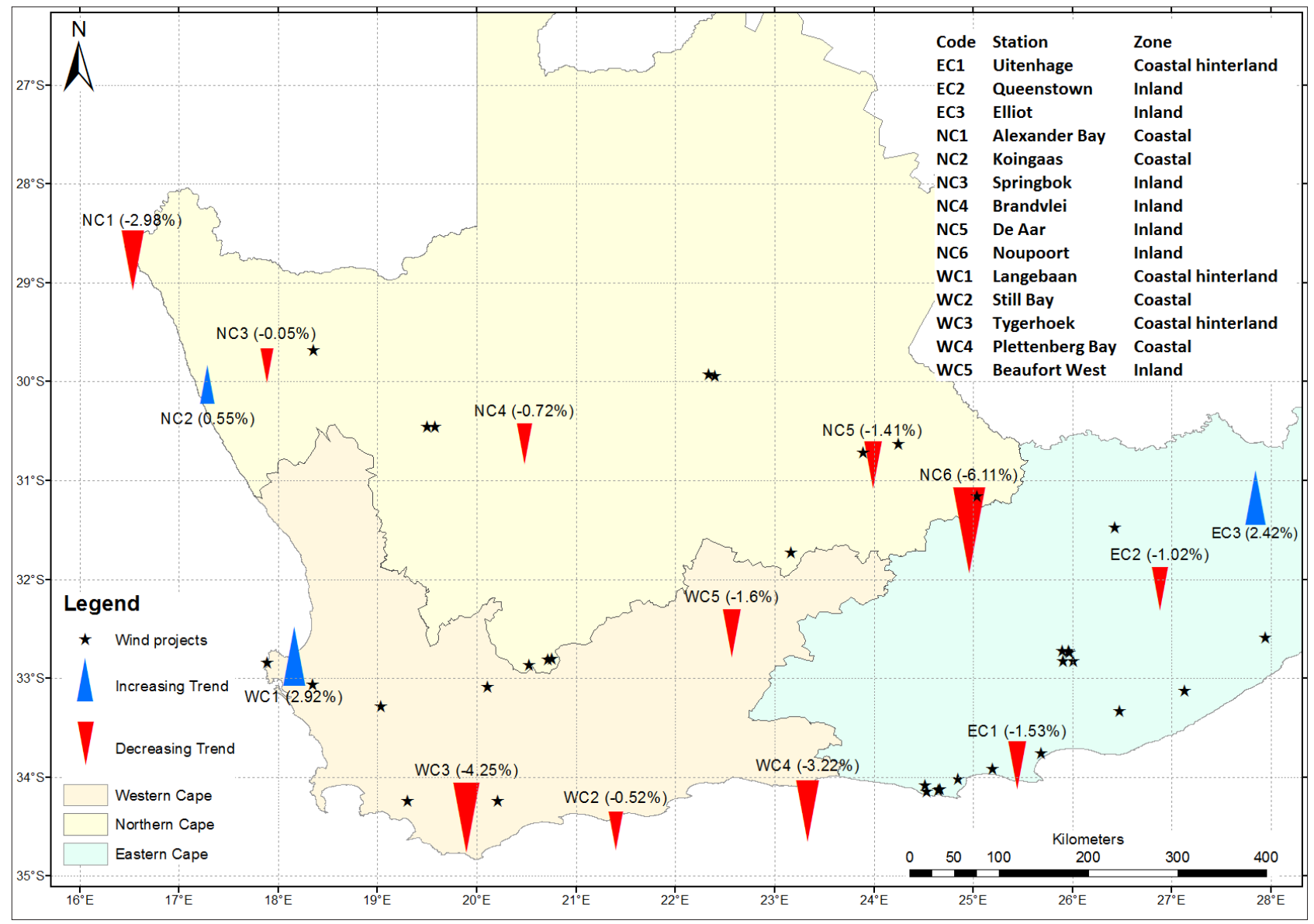

Figure 1: Mean short-term wind speed trends (1995-2014) mapped for the Northern, Western and Eastern Cape regions of South Africa. 
Given that the standard term of a wind power purchase agreement is 20 years, this period will allow a better understanding of potential wind speed variance and change over such a period of time for the stations concerned.

\section{Statistical characteristics}

When considering the Beaufort wind scale which is an empirical measure of observed wind speed, all 14 wind stations fall into one of two categories: 'light breeze' or 'gentle breeze'. Five (36\%) stations had mean conditions constituting a 'light breeze' (1.6-3.3 m/s), while the remaining nine (64\%) stations had mean conditions constituting a 'gentle breeze' (3.4-5.4 m/s) (Table 1). Thus, stations overall fall within the 'moderate' wind range, with highest speeds in the Northern Cape and 'light breeze' conditions being more typical to the Western and Eastern Cape regions.

For the study period (1995-2014), mean annual wind speed across the 14 stations was $3.79 \mathrm{~m} / \mathrm{s}$, but varied considerably from $5.13 \mathrm{~m} / \mathrm{s}$ at Koingaas (coastal zone; Northern Cape) to $2.51 \mathrm{~m} / \mathrm{s}$ at Tygerhoek (coastal hinterland; Western Cape). Alexander Bay (coastal zone; Northern Cape) has the highest inter-annual standard deviation of $0.91 \mathrm{~m} / \mathrm{s}$, while Plettenberg Bay (coastal zone; Western Cape) has the lowest at $0.33 \mathrm{~m} / \mathrm{s}$. The highest average monthly wind speed $(7.53 \mathrm{~m} / \mathrm{s})$ was recorded at Koingaas for December 2005, while the lowest $(1.62 \mathrm{~m} / \mathrm{s})$ was recorded at Tygerhoek for June 2003 (Table 1).

Notably, all three zones (coastal, coastal hinterland and inland) recorded decreasing mean annual wind speeds over the observation period. The coastal zone recorded the largest decrease $(-0.06 \mathrm{~m} / \mathrm{s},-1.54 \%)$, followed by the inland zone $(-0.05 \mathrm{~m} / \mathrm{s},-1.21 \%)$ and finally the coastal hinterland zone $(-0.03 \mathrm{~m} / \mathrm{s},-0.95 \%)$. The Eastern Cape inland zone is the only region which recorded an increasing mean annual wind speed over the observation period $(0.02 \mathrm{~m} / \mathrm{s}, 0.7 \%)$, but this increase is statistically insignificant at the $0.05 \%$ level (Figures 2 and 3 ).

Table 1: $\quad$ Wind speed statistics for various Cape stations (1995-2014)

\begin{tabular}{|c|c|c|c|c|c|c|c|c|}
\hline Code & Station & Zone & $\begin{array}{c}\text { Mean monthly } \\
(\mathrm{m} / \mathrm{s})\end{array}$ & $\begin{array}{c}\text { Max monthly } \\
(\mathrm{m} / \mathrm{s})\end{array}$ & $\begin{array}{c}\text { Min monthly } \\
(\mathrm{m} / \mathrm{s})\end{array}$ & $\begin{array}{c}\text { Standard } \\
\text { deviation } \\
(\mathrm{m} / \mathrm{s})\end{array}$ & $p$-value & $\begin{array}{c}\text { Statistically } \\
\text { significant trends }\end{array}$ \\
\hline EC1 & Uitenhage & Coastal hinterland & 3.14 & 4.22 & 2.10 & 0.42 & 0.39 & No \\
\hline EC2 & Queenstown & Inland & 3.24 & 4.52 & 2.09 & 0.50 & 0.62 & No \\
\hline EC3 & Elliot & Inland & 3.12 & 5.08 & 1.97 & 0.50 & 0.03 & Yes \\
\hline NC1 & Alexander Bay & Coastal & 4.36 & 6.63 & 2.55 & 0.91 & 0.25 & No \\
\hline NC2 & Koingaas & Coastal & 5.13 & 7.53 & 2.56 & 0.70 & 0.60 & No \\
\hline NC3 & Springbok & Inland & 4.48 & 6.73 & 3.51 & 0.49 & 0.88 & No \\
\hline NC4 & Brandvlei & Inland & 3.62 & 4.76 & 2.34 & 0.56 & 0.72 & No \\
\hline NC5 & De Aar & Inland & 4.66 & 6.29 & 3.28 & 0.68 & 0.51 & No \\
\hline NC6 & Noupoort & Inland & 3.88 & 5.50 & 2.25 & 0.73 & 0.01 & Yes \\
\hline WC1 & Langebaan & Coastal hinterland & 3.89 & 5.70 & 2.33 & 0.73 & 0.17 & No \\
\hline WC2 & Still Bay & Coastal & 3.67 & 4.56 & 2.85 & 0.38 & 0.97 & No \\
\hline WC3 & Tygerhoek & Coastal hinterland & 2.51 & 3.53 & 1.62 & 0.40 & 0.02 & Yes \\
\hline WC4 & Plettenberg Bay & Coastal & 3.23 & 4.11 & 2.10 & 0.33 & 0.01 & Yes \\
\hline WC5 & Beaufort West & Inland & 4.14 & 5.47 & 2.87 & 0.47 & 0.36 & No \\
\hline
\end{tabular}

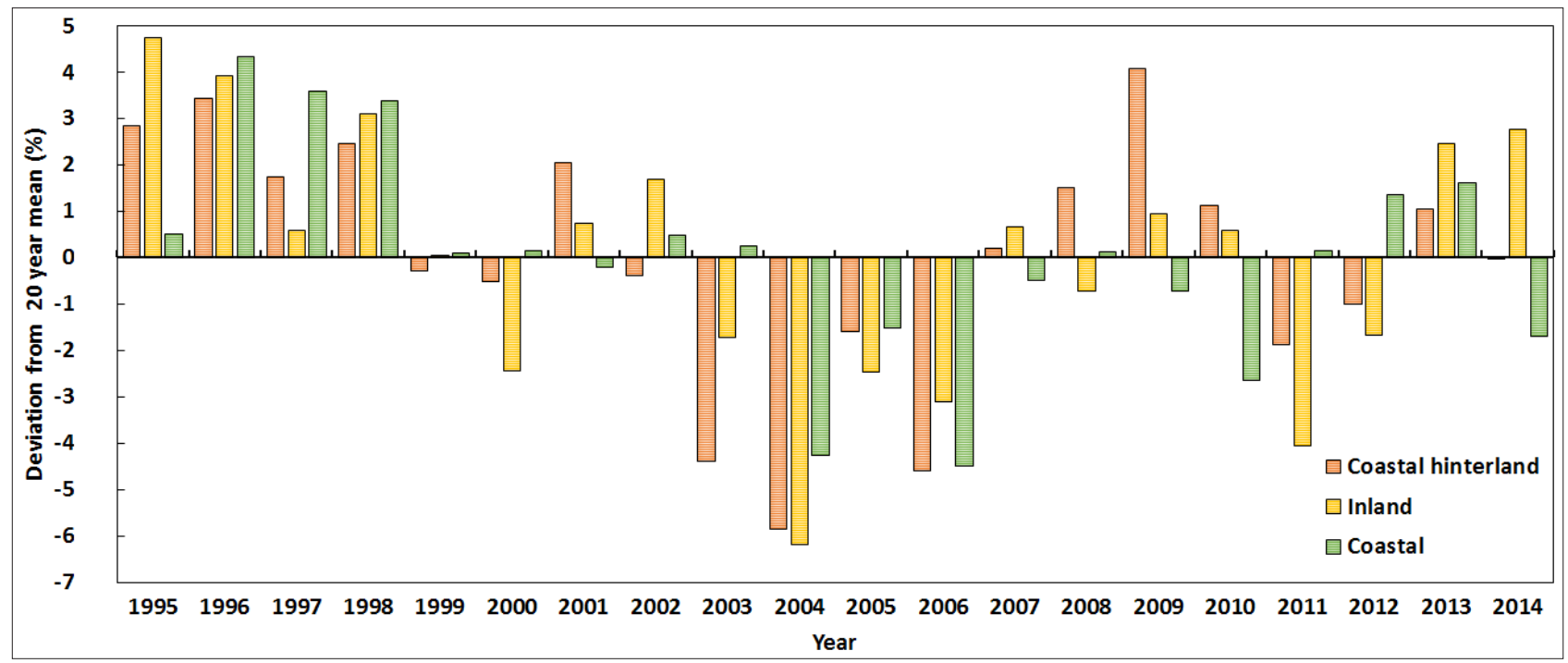

Figure 2: Mean annual wind speed variance per zone, based on mean annual short-term trends between 1995 and 2014 . 


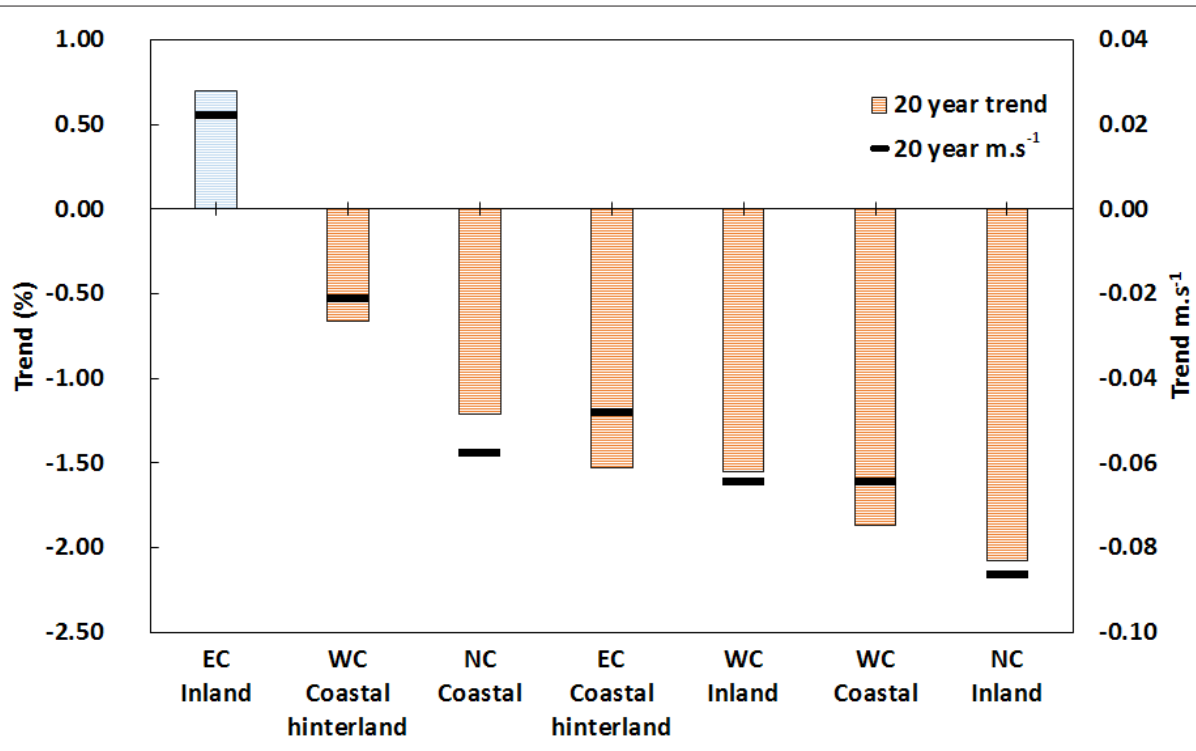

Figure 3: Mean wind speed trends per zone, based on mean short-term trends between 1995 and 2014.

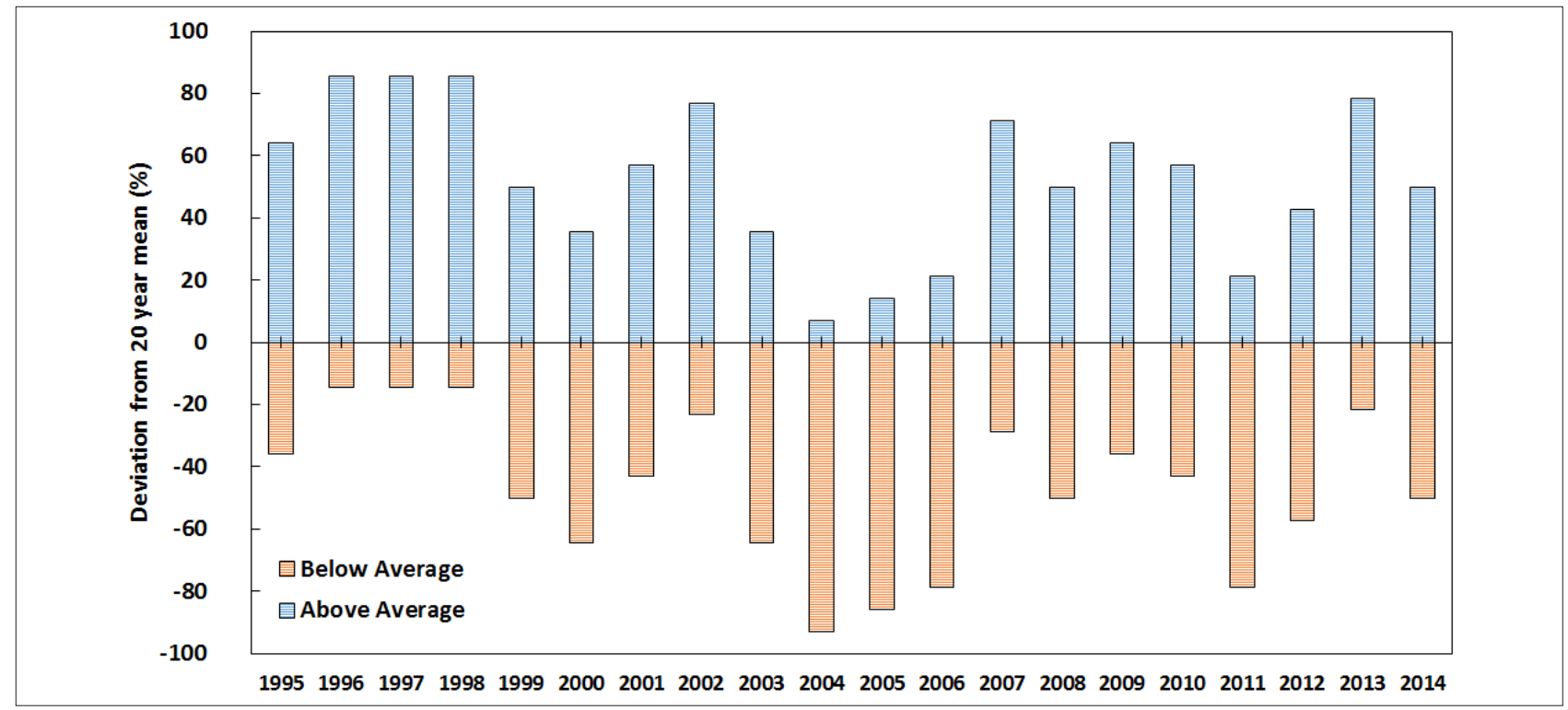

Figure 4: Deviation from mean wind speeds for the period 1995-2014.

\section{Monthly, seasonal and annual trends}

Mean annual wind speed generally decreased for the 14 stations over the period 1995-2014. Although a mean loss of $-0.05 \mathrm{~m} / \mathrm{s}(-1.25 \%)$ in annual wind speed is evident over the 20-year period, some stations (e.g. WC1, NC2 and EC3) experienced increasing trends (Figure 4). For the stations included in this study, both decreasing $(79 \%)$ and increasing $(21 \%)$ trends were recorded (Figure 1). Langebaan recorded the highest increasing trend of $0.12 \mathrm{~m} / \mathrm{s}(2.9 \%)$, while Noupoort recorded the highest decreasing trend of $-0.24 \mathrm{~m} / \mathrm{s}(-6.1 \%)$. Decreasing trends (11 stations) average $-0.08 \mathrm{~m} / \mathrm{s}(-2.1 \%)$, while the increasing trends (3 stations) average $0.07 \mathrm{~m} / \mathrm{s}(2 \%)$.

Over the 20-year period, mean increasing seasonal wind speeds were recorded for autumn $(0.11 \mathrm{~m} / \mathrm{s}, 2.87 \%)$ and winter $(0.06 \mathrm{~m} / \mathrm{s}, 1.49 \%)$. In contrast, mean decreasing wind speed trends were recorded for summer $(-0.11 \mathrm{~m} / \mathrm{s},-2.93 \%)$ and spring $(-0.09 \mathrm{~m} / \mathrm{s},-2.27 \%)$. The inland zone recorded the highest mean seasonal increase $(0.12 \mathrm{~m} / \mathrm{s}, 3.1 \%)$ during autumn, while the coastal hinterland zone recorded the highest mean decrease $(-0.13 \mathrm{~m} / \mathrm{s},-4.0 \%)$ during summer. Regionally, inland areas of the Eastern Cape recorded the highest increase $(0.16 \mathrm{~m} / \mathrm{s}, 4.9 \%)$ during autumn, while the Northern Cape coastal region recorded the largest decrease $(-0.23 \mathrm{~m} / \mathrm{s},-4.9 \%)$ during summer (Figures 5 and 6 ).
Over the 20-year period, mean annual wind speed trends were between $-0.012 \mathrm{~m} / \mathrm{s} /$ year $(-0.31 \% \mathrm{pa})$ for Noupoort and $0.006 \mathrm{~m} / \mathrm{s} /$ year $(0.15 \% \mathrm{pa})$ for Langebaan, with a mean decrease across all stations of $-0.002 \mathrm{~m} / \mathrm{s} /$ year $(-0.06 \%)$. The seasonal mean wind speed trends ranged from $-0.016 \mathrm{~m} / \mathrm{s} /$ year $(-0.36 \% \mathrm{pa})$ recorded in summer, to $0.011 \mathrm{~m} / \mathrm{s} /$ year $(0.26 \% \mathrm{pa})$ recorded in winter, both at Alexander Bay. Across all stations, mean seasonal wind speeds decreased by the highest margin $(-0.006 \mathrm{~m} / \mathrm{s} /$ year; $-0.15 \% \mathrm{pa})$ during summer.

For the 20 years assessed, $71 \%$ of stations recorded a decreasing mean wind speed trend $(-0.004 \mathrm{~m} / \mathrm{s} /$ year, $-0.1 \% \mathrm{pa})$, while $29 \%$ recorded increasing mean trends $(0.004 \mathrm{~m} / \mathrm{s} / \mathrm{year}, 0.1 \% \mathrm{pa})$. At a monthly scale, stations recorded a mean decrease of $-0.0016 \mathrm{~m} / \mathrm{s} /$ year $(-0.043 \% \mathrm{pa})$ for September through February, and a mean increase of $0.001 \mathrm{~m} / \mathrm{s} / \mathrm{year}$ $(0.035 \% \mathrm{pa})$ for March through August. The strongest mean decreasing trend of $-0.0023 \mathrm{~m} / \mathrm{s} / \mathrm{year}(-0.06 \% \mathrm{pa})$ was recorded in January, while the strongest mean increasing trend of $0.002 \mathrm{~m} / \mathrm{s} /$ year $(0.06 \% \mathrm{pa})$ was recorded in May. A high percentage $(86 \%)$ of stations recorded increasing wind speed trends during the autumn and winter months of March to August, while most stations (93\%) recorded decreasing trends during the spring and summer months of September to February (Figure 7). 


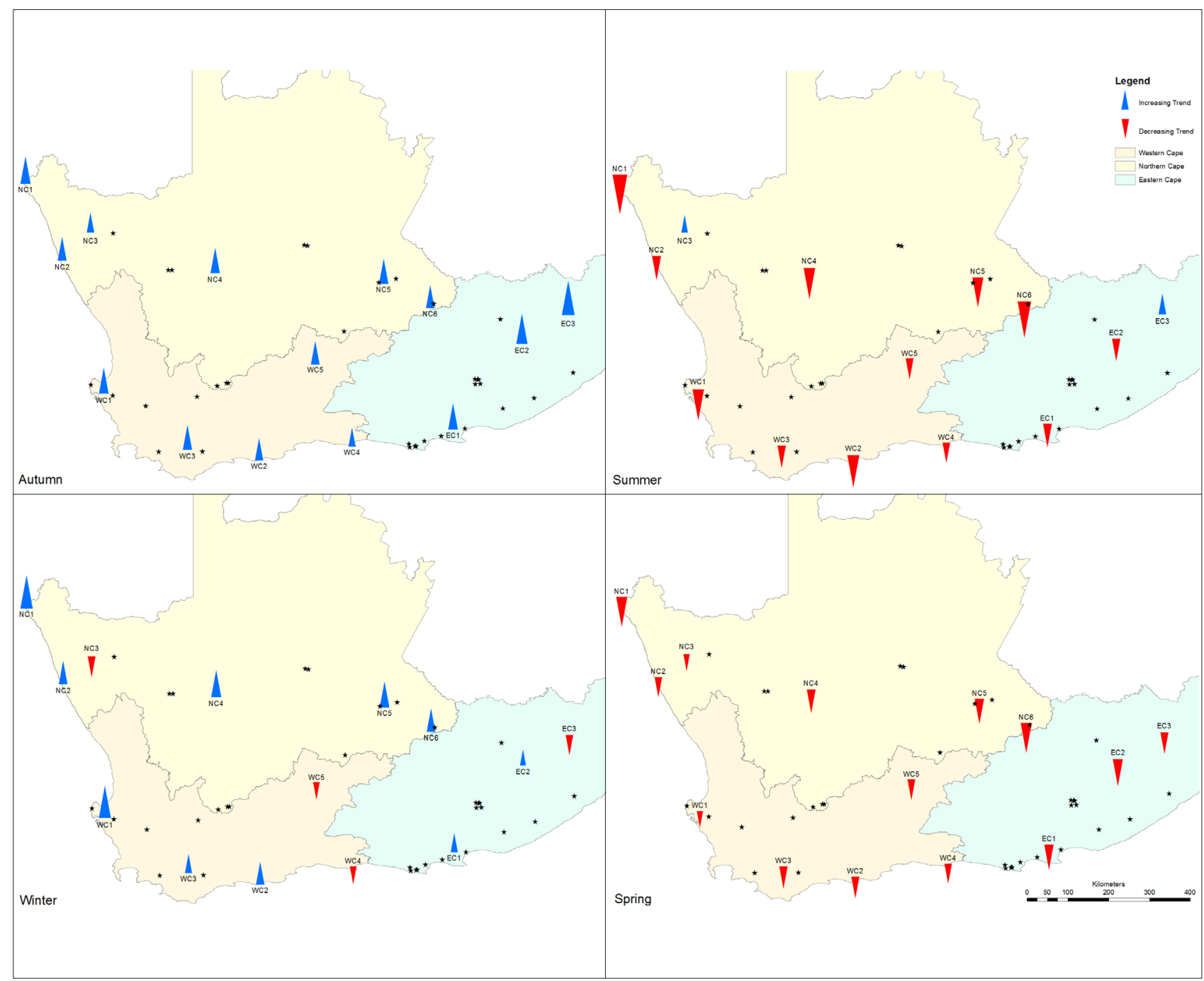

Figure 5: Map of seasonal wind speed trends for the period 1995-2014.

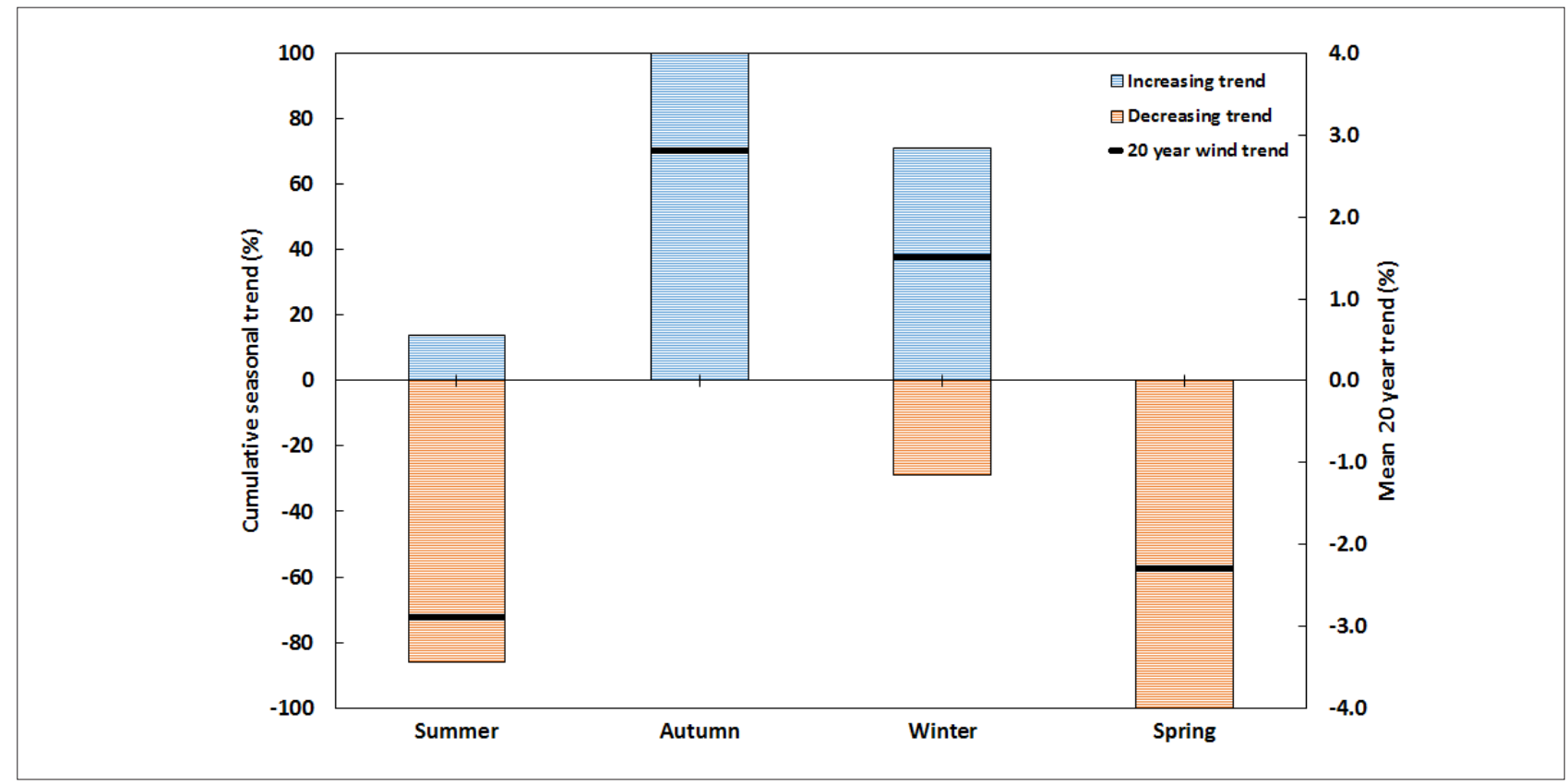

Figure 6: Mean seasonal wind speed trends for the period 1995-2014. 


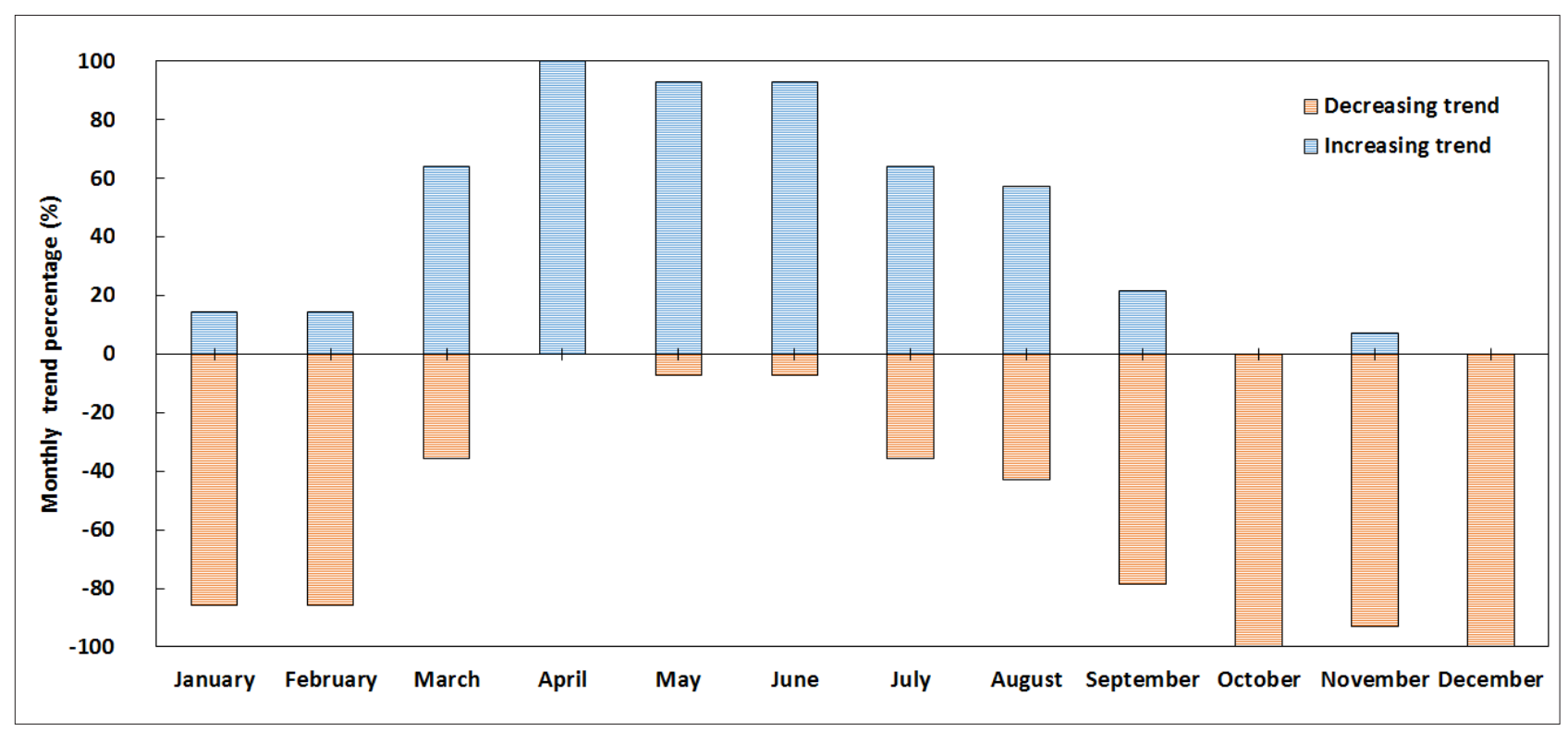

Figure 7: Mean monthly wind speed trend for the period 1995-2014.

All three geographic zones recorded mean decreasing wind speed trends; the coastal zone recorded the largest mean decrease $(-0.06 \mathrm{~m} / \mathrm{s}$, $-1.54 \%)$ followed by the inland zone $(-0.05 \mathrm{~m} / \mathrm{s},-1.21 \%)$ and finally the coastal hinterland zone $(-0.03 \mathrm{~m} / \mathrm{s},-0.95 \%)$. The Northern Cape inland region recorded the largest decrease $(-0.09 \mathrm{~m} / \mathrm{s},-2.07 \%)$ of all the study regions over the study period, which equates to an annual decrease of $-0.004 \mathrm{~m} / \mathrm{s} / \mathrm{year}(-0.10 \% \mathrm{pa})$. In contrast, the Eastern Cape inland region is the only region that recorded increases in mean wind speed $(-0.001 \mathrm{~m} / \mathrm{s} /$ year, $-0.04 \% \mathrm{pa})$, but these increases are statistically insignificant at the $0.05 \%$ level (Figures 2 and 3 ).

A key aspect to consider for wind power is inter-annual variability in wind speed. The Eastern Cape stations recorded the highest mean interannual variance $(4.3 \%)$, followed by the Western Cape (3\%) and finally the Northern Cape (2.7\%). When considering all stations over the study period, the mean inter-annual variability is $3.11 \%$; the Northern Cape inland region of Brandvlei recorded the lowest inter-annual variability of $1.79 \%$, while the Eastern Cape coastal hinterland region of Queenstown recorded the highest at $4.72 \%$. Across all stations, the lowest mean inter-annual variability (1.93\%) was recorded between 2001 and 2002, while the highest (4.31\%) was recorded between 2006 and 2007. The largest inter-annual variability (12.64\%) was recorded between 2003 and 2004 at the Northern Cape inland region of Noupoort.

\section{Discussion}

Changes in near-surface wind speed at various temporal scales may have several implications. A key impact in the South African context includes energy generation. Electricity generated from wind is derived from a well-known scientific mathematical expression $\left(P=\frac{1}{2} C p p A U^{3}\right)$, which implies that when wind speed is doubled or halved, available energy respectively increases or decreases eight-fold ${ }^{28}$ Over the 20 -year period, all three zones recorded a decrease in mean wind speed, with the coastal zone recording the largest decrease $(-0.06 \mathrm{~m} / \mathrm{s},-1.54 \%)$, followed by the inland zone $(-0.05 \mathrm{~m} / \mathrm{s},-1.21 \%)$ and coastal hinterland $(-0.03 \mathrm{~m} / \mathrm{s}$, $-0.95 \%$ ) (Figure 2). These decreases equate to a reduction in available energy of $3.7 \%, 1.8 \%$ and $0.9 \%$, respectively. According to McVicar et al. ${ }^{29}$, studies with more than 30 stations and in excess of 30 years of data have recorded a mean wind speed decrease of $-0.001 \mathrm{~m} / \mathrm{s} \mathrm{pa}$, which equates to a decrease of $-0.028 \mathrm{~m} / \mathrm{s}$ over a 20 -year period.

Between 1979 and 2008, several regions globally recorded average decreasing wind speed trends, including Europe $(-0.01 \mathrm{~m} / \mathrm{s} / \mathrm{year})$,
North America (-0.007 m/s/year), Central Asia (-0.016 m/s/year), South Asia $(-0.008 \mathrm{~m} / \mathrm{s} / \mathrm{year})$ and East Asia $(-0.012 \mathrm{~m} / \mathrm{s} / \mathrm{year}){ }^{30}$ In Africa, both increasing and decreasing wind speed trends have been recorded over the last 65 years (Table 2). For instance, Niger records the largest increasing trend of $0.065 \mathrm{~m} / \mathrm{s} /$ year (one station, 11 years data), while Cameroon records the largest decreasing trend of $-0.2 \mathrm{~m} / \mathrm{s} / \mathrm{year}$ (one station, 5 years data). The results of this study place the Cape regions of South Africa within a marginally decreasing wind speed trend of $-0.002 \mathrm{~m} / \mathrm{s} /$ year $(-0.06 \% \mathrm{pa})$ over the past 20 years (equating to a mean decrease of $-0.5 \mathrm{~m} / \mathrm{s},-1.25 \%$ ), quantifying to a decrease in available energy of $1.95 \%$. This decreasing trend does not pose any immediate risk to wind power projects in the Cape regions of South Africa. The allowance for inter-annual variability in a forecast energy yield model would account for any potential decrease of this nature.

\section{Summary}

This assessment confirms that mean regional near-surface wind speeds are insignificantly declining at 10 Cape stations at an average rate of $-0.002 \mathrm{~m} / \mathrm{s} /$ year (or $-0.05 \mathrm{~m} / \mathrm{s}$ over the 20-year study period from 1995 to 2014$)$. Only four stations (28.6\%) recorded statistically significant trends at the $0.05 \%$ level; of these $75 \%$ were decreasing trends. Coastal zones recorded a statistically larger decrease in mean wind speed compared to inland regions. When considering seasonal wind speed trends over the study period, decreasing trends were recorded in summer and spring and increasing trends were recorded in winter and autumn. Wind speed trends and variance measured over the research period (1995-2014) for the Cape stations in this study, would not have posed any risk to power generation from wind. As has been quantified, mean recorded wind speed decreases have been marginal under recent (last 20 years) climatic conditions and change, thus adding confidence to the justification by the South African government to procure additional wind-generated electricity capacity.

\section{Acknowledgements}

We acknowledge data provided by the South African Weather Service and financial support from the National Research Foundation of South Africa (grant \#102100).

\section{Authors' contributions}

M.W. performed the research, analysed the data and wrote the paper; S.G. performed key editorial reviews and provided research guidance. 
Table 2: $\quad$ Recent wind speed trends for various African sub-regions

\begin{tabular}{|c|c|c|c|c|c|}
\hline Country & Number of sites & Coordinates & Period & Trend (m/s/year) & Reference \\
\hline Niger & 1 site & $13^{\circ} \mathrm{N}, 2^{\circ} \mathrm{E}$ & 1984-1994 & 0.064 & 31 \\
\hline Tanzania & 1 site & $9^{\circ} \mathrm{S}, 35^{\circ} \mathrm{E}$ & $2001-2005$ & 0.063 & 32 \\
\hline Nigeria & 2 sites & $11-12^{\circ} \mathrm{N}, 11-13^{\circ} \mathrm{E}$ & 1969-1982 & 0.046 & 33 \\
\hline Egypt & 1 site & $24^{\circ} \mathrm{N}, 33^{\circ} \mathrm{E}$ & $1995-2003$ & 0.043 & 34 \\
\hline Algeria & 22 sites & $28-37^{\circ} \mathrm{N}, 2-15^{\circ} \mathrm{E}$ & $1973-2003$ & 0.005 & 35 \\
\hline Atlantic Coast & 24 sites & $15^{\circ} \mathrm{S}-21^{\circ} \mathrm{N}, 23^{\circ} \mathrm{W}-14^{\circ} \mathrm{E}$ & $1955-1985$ & 0.005 & 36 \\
\hline Mauritania and Senegal & 4 sites & $14-21^{\circ} \mathrm{N}, 15-17^{\circ} \mathrm{W}$ & $1951-1994$ & 0.001 & 37 \\
\hline Kenya & 1 site & $1^{\circ} \mathrm{S}, 37^{\circ} \mathrm{E}$ & 1979-2008 & -0.002 & 30 \\
\hline South Africa & 19 sites & $28-35^{\circ} \mathrm{S}, 16-28^{\circ} \mathrm{E}$ & 1995-2014 & -0.002 & This study \\
\hline North Africa & 150 sites & $10-37^{\circ} \mathrm{N}, 1^{\circ} \mathrm{W}-55^{\circ} \mathrm{E}$ & $1973-2003$ & -0.014 & 38 \\
\hline Ethiopia & 1 site & $7^{\circ} \mathrm{N}, 39^{\circ} \mathrm{E}$ & 1973-2003 & -0.022 & 39 \\
\hline Cameroon & 2 sites & $7-9^{\circ} \mathrm{N}, 13^{\circ} \mathrm{E}$ & 1990-1999 & -0.029 & 40 \\
\hline Libya & 1 site & $33^{\circ} \mathrm{N}, 13^{\circ} \mathrm{E}$ & $1993-2002$ & -0.087 & 41 \\
\hline Algeria & 8 sites & $24-37^{\circ} \mathrm{N}, 0-8^{\circ} \mathrm{E}$ & 2002-2006 & -0.091 & 42 \\
\hline Libya & 1 site & $33^{\circ} \mathrm{N}, 12^{\circ} \mathrm{E}$ & 1979-1988 & -0.116 & 43 \\
\hline Ghana & 1 site & $11^{\circ} \mathrm{N}, 0^{\circ} \mathrm{E}$ & $2001-2005$ & -0.200 & 44 \\
\hline Cameroon & 1 site & $10^{\circ} \mathrm{N}, 14^{\circ} \mathrm{E}$ & 1991-1995 & -0.200 & 45 \\
\hline Cameroon & 1 site & $10^{\circ} \mathrm{N}, 14^{\circ} \mathrm{E}$ & 1991-1995 & -0.240 & 46 \\
\hline
\end{tabular}

\section{References}

1. Global Wind Energy Council (GWEC) and Greenpeace. Global wind energy outlook 2014 [document on the Internet]. c2014 [cited 2015 0ct 24]. Available from: http://www.gwec.net/wp-content/uploads/2014/10/ GWE02014_WEB.pdf

2. Lombard A, Ferreira SLA. The spatial distribution of renewable energy infrastructure in three particular provinces of South Africa. Bullet Geogr. 2015;30(30):71-86. http://dx.doi.org/10.1515/bog-2015-0036

3. Walwyn DR, Brent AC. Renewable energy gathers steam in South Africa. Renew Sust Energ Rev. 2015;41:369-401. http://dx.doi.org/10.1016/j. rser.2014.08.049

4. National Energy Regulator of South Africa (NERSA). System adequacy outlook: Issue 6 [document on the Internet]. c2015 [cited 2015 0ct 13]. Available from: http://www.nersa.org.za/Admin/Document/Editor/file/News\%20and\%20 Publications/Publications/Archived\%20Issues/NERSA\%20System $\% 20$ Adequacy\%200utlook,\%20lssue\%20no\%206.pdf

5. South African Department of Energy (DoE). Renewable energy IPP procurement programme: Bid window 3: Preferred bidders' announcement [document on the Internet]. c2013 [cited 2014 Dec 09]. Available from: http://www.energy.gov.za/IPP/List-of-IPP-Preferred-Bidders-Window-three04Nov2013.pdf

6. Breslow PB, Sailor DJ. Vulnerability of wind power resources to climate change in the continental United States. Renew Energ. 2002;27(4):585-598. https://doi.org/10.1016/S0960-1481(01)00110-0

7. Sailor DJ, Smith M, Hart M. Climate change implications for wind power resources in the Northwest United States. Renew Energ. 2008;33(11):23932406. https://doi.org/10.1016/j.renene.2008.01.007

8. De Lucena AFP, Szklo AS, Schaeffer R, Dutra RM. The vulnerability of wind power to climate change in Brazil. Renew Energ. 2010;35(5):904-912. https://doi.org/10.1016/j.renene.2009.10.022
9. Wan H, Wang XL, Swail VR. Homogenization and trend analysis of Canadian near-surface wind speeds. J Climate. 2010;23(5):1209-1225. https://doi. org/10.1175/2009JCLI3200.1

10. Enloe J, O'Brian JJ, Smith SR. ENSO impacts on peak wind gusts in the United States. J Climate. 2004;17(08):1728-1737. http://dx.doi.org/10.1175/15200442(2004)017<1728:EIOPWG>2.0.C0;2

11. Pryor SC, Barthelmie RJ, Schoof JT. The impact of non-stationarities in the climate system on the definition of 'a normal wind year': A case study from the Baltic. Int J Climatol. 2005;05(25):735-752. https://doi.org/10.1002/ joc. 1151

12. Pryor SC, Ledolter J. Addendum to "wind speed trends over the contiguous United States". J Geophys Res-Atmos. 2010;115(D10), Art. \#D10103, 7 pages. https://doi.org/10.1029/2009JD013281

13. Takatama K, Minobe S, Inatsu M, Small JR. Diagnostics for near-surface wind response to the Gulf Stream in a regional atmospheric model. J Climate. 2015;28(1):235-255. https://doi.org/10.1175/JCLI-D-13-00668.1

14. Young IR, Zieger S, Babanin AV. Global trends in wind speed and wave height. Science. 2011;332(6028):451-455. https://doi.org/10.1126/ science. 1197219

15. Pryor SC, Barthelmie RJ. Long-term trends in near-surface flow over the Baltic. Int J Climatol. 2003;23(3):271-289. https://doi.org/10.1002/joc.878

16. Diab RD, Garstang M. Assessment of wind power potential for two contrasting coastlines of South Africa using a numerical model. J Climate Appl Meteorol. 1984;23(12):1645-1659. http://dx.doi.org/10.1175/15200450(1984)023<1645:AOWPPF>2.0.C0;2

17. Diab RD. Wind atlas of South Africa. Pretoria: Department of Mineral and Energy Affairs; 1995.

18. Hagermann K. Mesoscale wind atlas of South Africa [PhD thesis]. Cape Town: University of Cape Town; 2008. https://open.uct.ac.za/handle/11427/5287

19. Council for Scientific and Industrial Research (CSIR). Wind Atlas for South Africa (WASA). Pretoria: CSIR; 2010 [accessed 2016 Aug 05]. Available from: http://www.wasa.csir.co.za/ 
20. Ayodele TR, Jimoh AA, Mundal JL, Agee JT. Statistical analysis of wind speed and wind power potential of Port Elizabeth using Weibull parameters. J Energy South Afr. 2012;23(2):30-38. http://www.erc.uct.ac.za/sites/default/files/ image_tool/images/119/jesa/23-2jesa-ayodele-etal.pdf

21. Kruger AC. Wind climatology of South Africa relevant to the design of the built environment [PhD thesis]. Stellenbosch: Stellenbosch University; 2011. http://scholar.sun.ac.za/handle/10019.1/6847

22. Klink K. Trends in mean monthly maximum and minimum surface wind speeds in the coterminous United States, 1961 to 1990. Clim Res. 1999;13(03):193-205. http://dx.doi.org/10.3354/cr013193

23. Xu M, Chang CP, Fu C, Qi Y, Robock A, Robinson D, et al. Steady decline of East Asian monsoon winds 1969-2000: Evidence from direct ground measurements of wind speed. J Geophys Res. 2006;111(D24), Art. \#D24111, 8 pages. https://doi.org/10.1029/2006JD007337

24. Dadaser-Celik F, Cengiz E. Wind speed trends over Turkey from 1975 to 2006. Int J Climatol. 2013;34(6):1913-1927. http://dx.doi.org/10.1002/joc.3810

25. Kruger AC, Goliger AM, Retief JV, Sekele S. Strong wind climatic zones in South Africa. Wind Struct. 2010;13(1):37-55.

26. Herbst $L$, Lalk J. A case study of climate variability effects on wind resources in South Africa. J Energy South Afr. 2014;25(3):2-10. http://www.scielo.org.za/ scielo.php?pid=S1021-447X2014000300001\&script=sci_arttext\&ting=pt

27. Fant C, Schlosser AC, Strzepek K. The impact of climate change on wind and solar resources in Southern Africa. Appl Energ. 2016;161(01):556-564. http://dx.doi.org/10.1016/j.apenergy.2015.03.042

28. Zhao $\mathrm{H}, \mathrm{Wu} \mathrm{Q}, \mathrm{Hu} \mathrm{S}, \mathrm{Xu} \mathrm{H}$, Rasmussen $\mathrm{CN}$. Review of energy storage system for wind power integration support. Appl Energ. 2015;137:545-553. http:// dx.doi.org/10.1016/j.apenergy.2014.04.103

29. McVicar TR, Roderick ML, Donohue RJ, Li LT, Van Niel TG, Thomas A, et al. Global review and synthesis of trends in observed terrestrial near-surface wind speeds: Implications for evaporation. J Hydrol. 2012;416:182-205. http://dx.doi.org/10.1016/j.jhydrol.2011.10.024

30. Vautard R, Cattiaux J, Yiou P, Thépaut JN, Ciais P. Northern hemisphere atmospheric stilling partly attributed to increased surface roughness. Nat Geosci. 2010;3(11):756-761. http://dx.doi.org/10.1038/nge0979

31. Michels K, Potter KN, Williams JR. Calibration of EPIC for the simulation of wind erosion damage to pearl millet in West Africa, 1999. Proceedings of Wind Erosion - An International Symposium/Workshop; 1997 June 3-5; Manhattan, KS, USA. Available from: https://infosys.ars.usda.gov/ WindErosion/symposium/proceedings/michels.pdf

32. Kainkwa RM. Wind energy development in the African Great Lakes Region to supplement the hydroelectricity in the locality: A case study from Tanzania. Int J Env Chem Ecol Geol Geophys Engineer. 2010;4(1):214-218. http://www. waset.org/publications/ 15540

33. Hess TM. Trends in reference evapo-transpiration in the North East Arid Zone of Nigeria, 1961-91. J Arid Environ. 1998;38(1):99-115. http://dx.doi. org/10.1006/jare.1997.0327
34. Elsawwaf M, Willems P, Feyn J. Assessment of the sensitivity and prediction uncertainty of evaporation models applied to Nasser Lake, Egypt. J Hydrol. 2010;395(1-2):10-22. http://dx.doi.org/10.1016/j.jhydrol.2010.10.002

35. Mahowald NM, Ballantine JA, Feddema JA, Ramankutty N. Global trends in visibility: Implications for dust sources. Atmos Chem Phys. 2007;7:3309 3339. https://doi.org/10.1006/jare.1997.0327

36. Bigg GR. Comparison of coastal wind and pressure trends over the tropical Atlantic: 1946-1987. Int J Climatol. 1993;13(4):411-421. https://doi. org/10.1016/j.jhydrol.2010.10.002

37. Ozer P. Evolution des directions et des vitesses des vents de 1951 à 1994 sur la façade Atlantique de l'Afrique de l'Ouset du sud du Senegal au nord de la Mauritanie [Evolution of wind directions and speeds from 1951 to 1994 on the Atlantic coast of Africa from the southwest of Senegal to the north of Mauritania]. J Int Climatol. 1996;9:479-486. French. http://hdl.handle. net/2268/16143

38. Mahowald NM, Ballantine JA, Feddema J, Ramankutty N. Global trends in visibility: Implications for dust sources. Atmos Chem Phys. 2007;7(12):33093339. https://doi.org/10.5194/acp-7-3309-2007

39. Gebreegziabher Y. Assessment of the water balance of Lake Awassa Catchment, Ethiopia. Enschede: ITC; 2004. http://www.itc.nl/library/ papers_2005/msc/wrem/yemane.pdf

40. Tchinda R, Kaptouom E. Wind energy in Adamaoua and North Cameroon provinces. Energ Convers Manage. 2003;44(6):845-857. http://dx.doi. org/10.1016/S0196-8904(02)00092-4

41. Mohamed AA, Elmabrouk AM. Assessment of the wind energy potential on the coast of Tripoli [document on the Internet]. c2009 [cited 2016 Jun 01]. Available from: http://s3.amazonaws.com/zanran_storage/www.ontario-sea. org/ContentPages/42655881.pdf

42. Himri Y, Himri S, Boudghene Stambouli A. Assessing the wind energy potential projects in Algeria. Renew Sust Energ Rev. 2009;13(8):2187-2191. http://dx.doi.org/10.1016/j.rser.2009.03.003

43. El-Osta W, Belhag M, Klat M, Fallah I, Kalifa Y. Wind farm pilot project in Libya. Renew Energ. 1995;6(5-6):639-642. http://dx.doi.org/10.1016/09601481(95)00061-N

44. O'Higgins RC. Savannah woodland degradation assessments in Ghana: Integrating ecological indicators with local perceptions. Earth Environ. 2007;3(1):246-281. https://www.researchgate.net/publication/242328801_ Savannah_Woodland_Degradation_Assessments_in_Ghana_integrating_ ecological_indicators_with_local_perceptions

45. Nfah EM, Ngundam JM. Modelling of wind/diesel/battery hybrid power systems for far North Cameroon. Energ Convers Manage. 2008;49(6):12951301. http://dx.doi.org/10.1016/j.enconman.2008.01.007

46. Tchinda R, Kendjio J, Kaptouom E, Njomo D. Estimation of mean wind energy available in far north Cameroon. Energ Convers Manage. 2000;41(17):19171929. http://dx.doi.org/10.1016/S0196-8904(00)00017-0 